\title{
Tilbage til Østersøen
}

Af Ann-Sofie Dahl

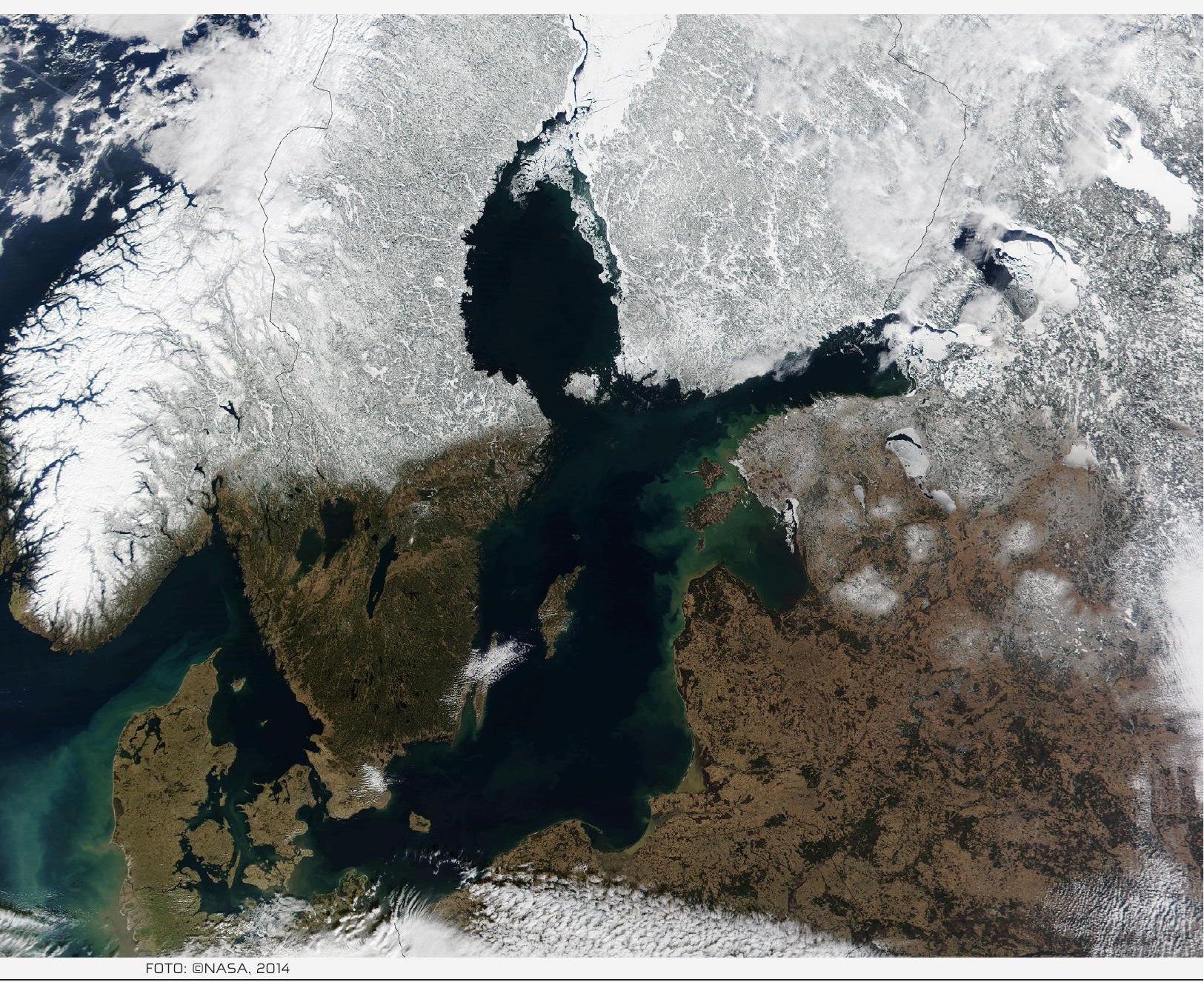


Østersøen er tilbage i centrum, fordi Rusland er tilbage med et nygammelt trusselsbillede, der minder om en verden, som vi troede, vi for længst havde forladt. Specielt for de to nordiske alliancefri lande, Sverige og Finland, har krisen i Ukraine været et chok og en brutal opvågning på flere måder.

Tilbage til Østersøen: sådan har mantraet været for Danmark og de øvrige nordiske lande, siden russiske soldater gik ind i Ukraine og annekterede Krim i foråret 2014. Efter en række år med deltagelse i internationelle militære operationer langt væk fra det nordiske område har præsident Vladimir Putins ekspansionistiske politik nu trukket de nordiske lande tilbage til den nordisk-baltiske region - og med Østersøen i centrum.

Normalt plejer man at sige, at de nordiske lande vender sig i forskellige retninger fra deres fælles horisont i nord. Ganske vist hænger de fem lande sammen i én region, selv om de hver for sig har mange særprægede politiske og kulturelle træk. Men historisk har de stået ryg mod ryg og vendt sig hver sin vej i forhold til omverdenen. Eller i flere forskellige retninger: Danmark mod syd, Norge og Island har kigget mod vest, mens Sverige og Finland har haft fuld opmærksomhed på, hvad der sker mod øst.

$\mathrm{Nu}$ har alle de nordiske lande på en eller anden måde igen blikket rettet mod øst, selv om de også har bibeholdt deres nationale tilgang til verden. Østersøen er tilbage i centrum, fordi Rusland er tilbage med et nygammelt trusselsbillede, der minder om en verden, som vi troede, vi for længst havde forladt.

Det er ikke en ny kold krig; den konflikt, vi ser i dag mellem Rusland og Vesten er ikke global som i gamle dage. Og den er heller ikke ideologisk som den kolde krig mellen Vesten og det sovjetiske system, der ikke kun var en militær konflikt, men i lige så høj grad en krig om idéer, om 'hearts and minds'.

Sådan er det trods alt ikke i dag, selv om der tydeligt er tale om to vidt forskellige måder at forstå det internationale system, og dets grundlæggende principper som territorial suverænitet og den legitime - og illegitime - brug af militær magt.

\section{Ikke mere partner}

I to årtier efter Berlinmurens fald var Rusland en partner til Vesten, med en særlig status gennem The NATO Russia Council. I de seneste par år er dette råd de facto ophørt med at fungere, da der i stigende grad har været en næsten total mangel på interesse fra russisk side. Denne udvikling var ét - omend ikke det eneste - tegn på, at den russiske stormagt var på vej tilbage på verdensscenen og var ved at forlade samarbejdet med Vesten.

Georgien i 2008 var et første skridt. Med Ukraine-krisen er det blevet helt tydeligt, at Georgien ikke var én enkelt og isoleret begivenhed, men et mønster og udtryk for en ny holdning fra russisk side: landet havde simpelthen meldt sig ud af det internationale samfund. Så nyttede det ikke meget, at USA kom løbende med sin restart knap.

$\mathrm{Nu}$ er Østersøen så igen blevet til et strategisk centrum, takket være præsident Putin, om man så må sige. Den faktiske, geografiske grænse mellem NATO

Ann-Sofie Dahl er Senior Research Fellow ved Center for Militære Studier og svensk docent i international politik. Hendes seneste forskningsrapport for NATO Defense College, NORDEFCO and NATO: 'Smart Defence' in the North? udkom i maj 2014. 
og Rusland går selvfølgelig ikke dér; den er flyttet østpå med de tre baltiske landes medlemskab af NATO.

Men med den intense militære aktivitet, der har været i Østersøen i de seneste år, med flere store øvelser fra begge sider - og med den russiske Zapad som den afgjort største, med op til 150.000 mand på land og til søs - og med den ene russiske provokation efter den anden mod de to alliancefri lande Sverige og Finland, er Østersøen igen blevet den scene, hvor øst og vest mødes med deres militære isenkram.

\section{Danmark mærker det}

Danmark mærker det ligeledes i kraft af sin tilstedeværelse i Baltikum, hvor russiske fly bevæger sig helt tæt på den baltiske - NATOs - østgrænse. Så tæt, at de danske piloter kan kigge de russiske kolleger i øjnene fra deres F-16 fly.

At Danmark er tilbage med fregatter i Østersøen og med soldater og fly on location i Baltikum, er yderligere et sikkert tegn på de nye tider. I halvfemserne var Danmark som bekendt det førende aktivistiske land i Østersø-regionen, som efter hårdt arbejde og trods megen modstand fik de tre baltiske lande med i NATO. I dag ser vi, hvor heldigt det var, at denne mission lykkedes; ellers ville der nok være russiske soldater - eller mystiske små grønne mænd - også i de baltiske lande.

Efter denne vellykkede mission vendte Danmark sig mod vest med fokus på den bilaterale relation med USA. Denne strategi har bragt det lille skandinaviske land helt til tops som en af supermagtens kæreste venner - og det var ikke kun i Anders Fogh Rasmussens tid.

Bemærk, hvor energisk Helle Thorning-Schmidt var i sin støtte til præsident Obamas intervention i Syrien - som så ikke blev til noget.

Da de fire nordiske statsministre og den finske præsident i september 2013 spiste middag med den amerikanske præsident i Stockholm, stod Danmark helt alene blandt de nordiske lande i sin stærke støtte til en intervention under amerikansk ledelse uden FN-mandat.

\section{Neutral eller alliancefri}

Mens Danmark sammen med USA rettede opmærksomheden mod Irak og Afghanistan, og Norge mere og mere vendte mod Arktis, var der kun de to alliancefri nordiske lande tilbage til at beskæftige sig med den regionale sikkerhed i Østersøen. De to var - af naturlige, geografiske grunde - stadig i Østersøen, selv om de også bevægede sig ud i verden på internationale opgaver med NATO.

At Sverige og Finland i 2014 fortsætter med at holde fast i deres alliancefri sikkerhedsdoktriner, og endnu ikke har fulgt de øvrige tre nordiske lande, der har været med i NATO siden starten i 1949, er svært at forstå for mange uden for de to lande og også for mange derhjemme.

Især fordi de trods forskellige sikkerhedspolitiske doktriner er stærkt vestligt orienterede og har haft et særdeles tæt militært og politisk samarbejde med NATO, siden de meldte sig ind i Partnership for Peace i 1994. Siden har de gradvist bevæget sig lidt tættere på NATO; nu er de for eksempel begge med i NATO Response Force, og er tæt på at afslutte forhandlingerne om Host Nation Support aftaler med NATO.

Sverige var også langt tidligere involveret i et meget tæet samarbejde med NATO. I mange år under den kolde krig havde Sverige et tophemmeligt militært samarbejde med NATO, primært med de to skandinviske naboer og Storbritannien. Det gik så godt - og langt - at Sverige faktisk uformelt blev omtalt som 'Det syttende medlemsland' i NATO - den gang forsvarsalliancen kun havde 16 medlemslande!

Men det svenske samarbejde var altså tophemmeligt og ikke noget, som det svenske folk kendte til. Ikke engang den daværende udenrigsminister, Östen Undén, der 
Mens Danmark sammen med USA rettede opmærksomheden mod Irak og Afghanistan, og Norge mere og mere vendte mod Arktis, var der kun de to alliancefri nordiske lande tilbage til at beskæftige sig med den regionale sikkerhed i Østersøen. De to var - af naturlige, geografiske grunde - stadig i Østersøen, selv om de også bevægede sig ud i verden på internationale opgaver med NATO.

var meget positiv over for Sovjetunionen, kendte noget til det på daværende tidspunkt. Svenskerne fik hele tiden at vide, at Sverige var strengt neutral mellem de to blokke. Men mange gik dog ud fra, at USA og NATO alligevel ville komme Sverige til undsætning, hvis det blev angrebet - og at fjenden ville komme fra øst, var der ikke ret mange svenskere, som var i tvivl om.

I dag er hverken Sverige eller Finland 'neutrale' mere. Siden de to lande blev medlemmer af EU i 1995, har de droppet 'neutralitet' og skiftet begrebet ud med 'alliancefrit'. Det var også den rigtige terminologi under den kolde krig, da et land ifølge folkeretten kun er neutralt i krig. Ellers er det alliancefrit.

\section{Sveriges kælenavn}

Gennem de sidste tyve år er samarbejdet med NATO så endelig blevet helt åbent og officiellt. Ja, det er nu så tæt, at Sverige endnu en gang har fået et kælenavn af NATO, denne gang som alliancens 'Partner number one' efter den vellykkede indsats i NATOs Operation Unified Protector i Libyen i 2012. Men der er hård konkurrence om titlen fra blandt andet og i første række - Finland.

De to lande samt de øvrige contributing partners - altså partnerlande der bidrager militært og deployerer til NATOs operationer - har i det sidste årti vænnet sig til at kunne vandre ind og ud af NATOs hovedkvarter. Især har deltagelsen i ISAF i Afghanistan åbnet alle døre - næsten - mellem NATO og partnerlande som Sverige og Finland. I løbet af de ti år, hvor landene har haft base i Mazar-el-Sharif i den nordlige del af Afghanistan, har de efterhånden fået en helt unik adgang til og indblik i NATOs daglige operative men også politiske arbejde, og de har formentlig også haft en hel del indflydelse på udviklingen.

Grænsen mellem allieret og partner var selvfølgelig ikke helt udvisket i ISAF, men det var tæt på; så tæt, at der ifølge mange svenskere og finner (og især mange svenske og finske politikere) ikke har været den helt store grund til at tage det sidste skridt og ansøge om medlemskab i forsvarsalliancen.

For de to nordiske alliancefri lande - eller allianceløse, som Carl Bildt tidligere plejede at sige - har krisen i Ukraine været et chok og en brutal opvågning på flere måder. Helt åbenlyst, fordi den russiske annektering af Krim og den russiske brug af militær magt i den østlige del af landet simpelthen var provokerende og uventet. Men også fordi det pludselig stod klart for dem, at det gode partnerskab med NATO ikke mere var til megen nytte i den nye verden post-foråret 2014.

Efter alle de år, hvor Sverige og Finland og de andre operationelle partnere - altså havde vænnet sig til at være med langt inde i NATO, var det traumatisk pludselig at blive mødt af lukkede døre. Med fornyet fokus på Artikel 5 og det territoriale forsvar er det nu 'members only' i NATO - også for 'partners number one and two'.

Denne specielle status kan Sverige og Finland ikke længere bruge til så meget som for kun et halvt år siden. Man prøver nu at finde mulige veje for at igen komme tættere på NATO, som for eksempel de 
Host Nation Support-aftaler, der tidligere er nævnt, og så militære øvelser, masser af øvelser med NATO.

\section{Øvelser, øvelser, øvelser}

Siden den russiske aggression mod Ukraine startede i slutningen af februar, har der været stort fokus på maritime øvelser i Østersøen for alle de nordiske landes vedkommende.

Ellers er den svenske specialitet jo fly selv om det ikke er lykkedes at få de nordiske naboer til at købe den svenske stolthed, JAS Gripen. I sommer kom meddelelsen om, at SAAB til sidst - efter mange år, hvor svenskerne energisk havde prøvet at overbevise danskerne om, at Gripen er det bedste kampfly - havde valgt at trække sig fra den danske konkurrence.

Til gengæld er Sverige god til selv at bruge sit eget kampfly. Ved Libyen-operationen var der røster fremme om, at Sverige kun ville deltage for at få endnu en mulighed for at fremvise sit flotte kampfly på det internationale marked. Kritikken var ikke fair og heller ikke rigtig. Det drejede sig mere om at fremvise Sverige for NATO som en operational og contributing partner i topklasse.

Finland var ikke med i Libyen-operationen, men begge lande ses sammen med Norge hver uge i luften over Lapland, hvor kampfly fra de nationale baser i Kallax, Bodø og Rovaniemi øver Cross Border Training (CBT). Danmark har været med i en sydlig version af øvelsen, Cross Border Training South, og er nu også ved at komme med i Lapland, da de to dele af CBT er slået sammen i én stor operation, der dækker fra nord til syd.

CBT er det virkelige 'flagskib' i NORDEF$\mathrm{CO}$, det nordiske forsvarssamarbejde, som i årene siden 2009 er vokset til at blive et meget omfattende samarbejde mellem de fem lande. Det var i øvrigt også i 2009, at den tidligere norske udenrigsminister, Thorvald Stoltenberg, afleverede sin rapport om nordisk samarbejde i udenrigs-og forsvarspolitiken.
At det præcist skete på dette tidspunkt, var langt fra nogen tilfældighed. I 2009 var den nordiske region for alvor vendt tilbage i strategisk forstand. Med den smeltende is i Arktis og nye trusselsbilleder gjorde geopolitiken et comeback i den nordlige del af Europa.

Stoltenberg-rapporten var til stor inspiration for NORDEFCO-samarbejdet, som har implementeret, eller prøvet at implementere, flere af rapportens forslag. The Iceland Air Meet (IAM14) i februar 2014, hvor de to alliancefri nordiske lande øvede luftovervågning over Island sammen med flere NATO-lande og med Norge som vært, var et godt eksempel på det.

Oprindeligt ville Sverige også deltage i den 'rigtige' luftovervågning, altså NATOs Air Policing Mission, men det nægtede nogle NATO-lande at acceptere. De havde allerede protesteret mod den svenske tendens til at bevæge sig helt op mod den yderste grænse mellem partner og allieret.

\section{Virker det?}

Der er også mange forskellige bud på, hvordan NORDEFCO virker, og om samarbejdet egentlig virker. Et meget vellykket samarbejde, siger nogle med kendskab til det komplekse NORDEFCO, som rummer mange hundrede fælles projekter og programmer - fra de store flotte CBT-øvelser over Lapland til nordisk uddannelse og fælles kurser hele vejen ned til fælles indkøb af 'søm og batterier'.

Andre peger på de mislykkede materielprojekter - procurement - hvor det ikke er lykkedes at samle de nordiske lande omkring indkøb og udvikling af for eksempel lastbiler, helikoptere - og kampfly - som bevis på, at NORDEFCO ikke virker. Denne kritik hører man meget af i Danmark, hvor mange fra starten har haft lavere forventninger til det nordiske projekt, og hvor mange åbenbart også synes, at det kun er noget for de to alliancefrie lande.

Det er da også Finland og Sverige, der 
foretager de største investeringer i NORDEFCO, politisk og militært. Et flertal af de mange fælles projekter har enten svensk eller finsk deltagelse - og tit begge dele. Sverige og Finland har også indgået en bilateral aftale om fordybet militært samarbejde.

For de alliancefrie lande er det nordiske samarbejde en vej til endnu tættere samarbejde med NATO. Og NORDEFCO lyder jo heller ikke så provokerende som NATO for de neutralitets-nostalgiske dele af befolkningerne.

Især i Stockholm - ikke så meget i Helsinki - har regeringen desuden hentet politisk inspiration i Stoltenbergs seneste forslag om en nordisk solidaritetserklæring. En sådan har de tre NATO-lande selvfølgelig allerede, så for de tre er det lidt overflødigt. Men Sverige har si- den 2009 haft sin egen 'Solidaritetsdeklaration', hvor det alliancefri land lover at hjælpe sine europæiske og nordiske naboer, hvis og når de har brug for det, og tillige erklærer sig parat at modtage assistance udefra.

Dette var nyt for Sverige. Men det er selvfølgelig kun en unilateral erklæring uden sikkerhedsgarantier som NATO-pagtens Artikel 5. Deklarationen manglende simpelthen substans, mente mange kritikere.

Med Ukraine-krisen er denne mangel blevet akut. De russiske provokationer ved de svenske og finske grænser og de lukkede døre til NATO-hovedkvarteret - og flere af de vigtigste dele af samarbejdet - har tydeligt vist, hvor sårbare de alliancefrie partnerlande er. Men finsk og svensk medlemskab af NATO er desværre stadig langt væk. 